\title{
Equatorial middle atmospheric chemical composition changes during sudden stratospheric warming events
}

O. Nath and S. Sridharan

National Atmospheric Research Laboratory, Department of Space, Gadanki 517 112, India Received: 9 July 2015 - Accepted: 11 August 2015 - Published: 4 September 2015 Correspondence to: S. Sridharan (susridharan@narl.gov.in)

Published by Copernicus Publications on behalf of the European Geosciences Union.
Chemical

composition during

SSW

O. Nath and S. Sridharan

\section{Title Page}

Abstract

Introduction

Conclusions

References

Tables

Figures

14

4

Back

Close

Printer-friendly Version

Interactive Discussion 


\section{Abstract}

Chemical composition data obtained from the Microwave Limb Sounder (MLS) and Michelson Interferometer for Passive Atmospheric Sounding (MIPAS) instruments onboard EOS-Aura and ENVISAT satellites are used to investigate the variation of ozone

$5\left(\mathrm{O}_{3}\right)$, water vapor $\left(\mathrm{H}_{2} \mathrm{O}\right)$ and methane $\left(\mathrm{CH}_{4}\right)$ volume mixing ratios $(\mathrm{VMRs})$ in the height range $20-60 \mathrm{~km}$ over the equatorial region during the sudden stratospheric warmings (SSWs) of 2004, 2009 and 2012, the occurrence of which are identified using the ERA (European Center for Medium Range Weather Forecasting Reanalysis) Interim temperature and zonal wind data sets. It is found that the $\mathrm{O}_{3}$ VMR shows increment whereas

$\mathrm{H}_{2} \mathrm{O}$ VMR shows decrement during the SSW event and the possible reasons for these changes in the VMRs are investigated. In the upper stratosphere, the source of water vapor is oxidation of $\mathrm{CH}_{4}$ which takes place either by hydroxyl $(\mathrm{OH})$ or by atomic oxygen (O). However, the OH VMR available for the year 2009 SSW event does not show any significant variation. The decrease of zonal mean MLS temperature over the equator during the SSW suggests that the rate of the reaction of ozone production $\left(\mathrm{O}+\mathrm{O}_{2} \longrightarrow \mathrm{O}_{3}+\mathrm{M}\right)$, which increases with decreasing temperature, shifts the $\mathrm{O} / \mathrm{O}_{3}$ ratio towards $\mathrm{O}_{3}$, resulting in the decrease of $\mathrm{CH}_{4}$ oxidation and consequent decrease in water vapor.

\section{Introduction}

20 Sudden stratospheric warming (SSW) is a high latitude wintertime phenomenon which is characterized by a sudden enhancement in temperature by several kelvins at $10 \mathrm{hPa}$ and above, followed by a deceleration and even sometimes, reversal of the zonal westerly wind to easterly. Scherhag (1952) was the first who detected a SSW by a radiosounding over Berlin. The SSWs occur in winter when planetary waves interact with the background flow (Matsuno, 1971). Breaking and dissipation of westward propagating planetary waves at stratospheric altitudes decelerate or even reverse the prevailing
ACPD

15, 23969-23988, 2015

\section{Chemical}

composition during

sSW

O. Nath and S. Sridharan

Title Page

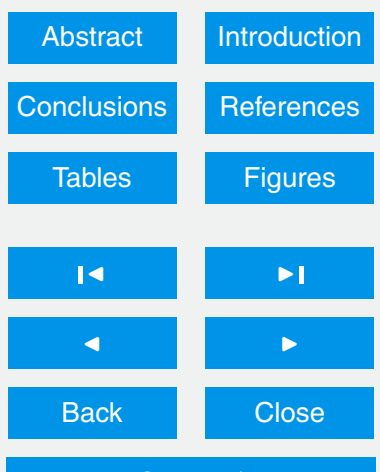

Full Screen / Esc

Printer-friendly Version

Interactive Discussion 
eastward flow of the polar winter time stratosphere. The SSWs are often accompanied by either a displacement of the polar vortex toward midlatitudes or an elongation which results in splitting of the vortex into daughter vortices. Though the SSW is a high latitude phenomenon, it influences the thermal structure, circulation and distribution 5 of minor constituents globally. First observational case studies regarding stratospheric chemical composition changes during the SSW were performed using in situ (Dutsch and Braun, 1980) and SAGE I satellite measurements (Wanget et al., 1983). Due to the availability of several satellite observations in the recent decades, there have been many reports on chemical composition changes at high-latitudes during the ma10 jor SSW of 2004, 2006 and 2009 (Manney et al., 2008a, b, 2009; Randel et al., 2006, 2009). Using Sounding of Atmosphere by Broadband Emission radiometry (SABER) on board Thermosphere-lonosphere-Mesosphere Energetics and Coupling (TIMED) satellite data sets, Siskind et al. (2007) observed elevation of stratopause and a downward mesospheric transport of NO during the 2006 SSW event. Manney et al. (2009) 15 investigated stratospheric chemistry of polar vortex during the 2009 and 2006 SSW events and they observed downward descent of $\mathrm{CO}, \mathrm{CH}_{4}$ and $\mathrm{H}_{2} \mathrm{O}$ from mesosphere during the decay of vortex fragments. Similarly, Salmi et al. (2011) also reported about the dowward transport of $\mathrm{NO}_{x}$ from mesosphere to upper stratosphere, though the $\mathrm{NO}_{x}$ involved catalytic ozone production/depletion cycle was shown to be ineffective in upper stratosphere. Using Global Ozone Monitoring by Occultation of Stars (GOMOS) data sets, Sofieva et al. (2012) observed strong horizontal mixing of $\mathrm{NO}_{2}$ with outside-vortex air and large $\mathrm{NO}_{3}$ enhancement correlating with the temperature enhancment. Damiani et al. (2014) also investigated a few chemical constituents $\left(\mathrm{O}_{3}, \mathrm{ClONO}_{2}, \mathrm{HCl}, \mathrm{ClO}, \mathrm{CO}\right.$, $\mathrm{NO}_{x}, \mathrm{CH}_{4}$ etc.) over polar region for a few SSW events. They found increment in ozone of methane $\left(\mathrm{CH}_{4}\right)$, they observed temporal evolution after the SSW events which they attributed to ingression of mid-latitude air. Using ground based microwave radiometer observations from 20 to $70 \mathrm{~km}$ over Bern (Switzerland), Flury et al. (2009) observed decrease of ozone and increase of $\mathrm{H}_{2} \mathrm{O}$ during the vortex breakdown period due to

\section{ACPD}

15, 23969-23988, 2015

Chemical

composition during

SSW

O. Nath and S. Sridharan

Title Page

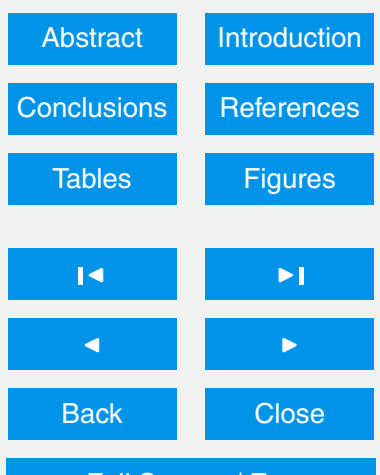

Full Screen / Esc

Printer-friendly Version

Interactive Discussion 
mixing of humid air from subtropical mesosphere. Tschanz and Kampfer (2015) also observed increase of water vapor over Sodankylä, Finland $\left(67.4^{\circ} \mathrm{N}, 26.6^{\circ} \mathrm{E}\right)$ derived from the middle atmospheric water vapor radiometer (MIAWARA) measurements.

There are only few studies over the equatorial region and low-latitudes on chemical 5 composition changes during the SSW events, although enhancement of ozone mixing ratio has consistently been observed (Sridharan et al., 2012; Nath et al., 2015). Sridharan et al. (2012) suggested that the enhancement of the equatorial and low-latitude ozone during the SSW event could be due to weakening of Brewer-Dobson circulation (BDC) responsible for transporting ozone to higher latitudes due to decrease in plane10 tary wave activity. In the present study, changes in chemical composition in the upper stratosphere over the equator during a few SSW events are investigated and an attempt is made to give a feasible chemical interpretation about the observed variations.

\section{Data sets used}

\subsection{MLS data for the equatorial $\mathrm{O}_{3}, \mathrm{H}_{2} \mathrm{O}$ VMR and temperature}

15 The Earth Observing System (EOS) Microwave Limb Sounder (MLS) is one of the four instruments on the NASA's EOS Aura satellite, which is part of NASA's A-train group of Earth observing satellites, launched on 15 July 2004 (Manney et al., 2005). The MLS makes measurements of atmospheric composition, temperature, humidity and cloud ice globally both day and night. It observes thermal microwave emission from Earth's "limb" (the edge of the atmosphere) viewing forward along the Aura spacecraft flight direction, scanning its view from the ground to $\sim 90 \mathrm{~km}$ every $\sim 25 \mathrm{~s}$. Aura is in a near-polar $705 \mathrm{~km}$ altitude orbit. As Earth rotates underneath it, the Aura orbit stays fixed relative to the sun to give daily global coverage with $\sim 13$ orbits per day. MLS is giving data since August 2004. In this present study we used MLS Version 3 VMR data of ozone $\left(\mathrm{O}_{3}\right)$ and temperature $(T)$ for 2009 and 2012 SSWs and water vapor $\left(\mathrm{H}_{2} \mathrm{O}\right)$ during the SSWs of 2004, 2009 and 2012 to study their variation in upper stratosphere.

\section{ACPD}

15, 23969-23988, 2015

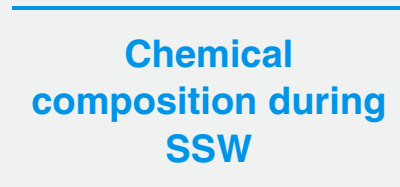

O. Nath and S. Sridharan

Title Page

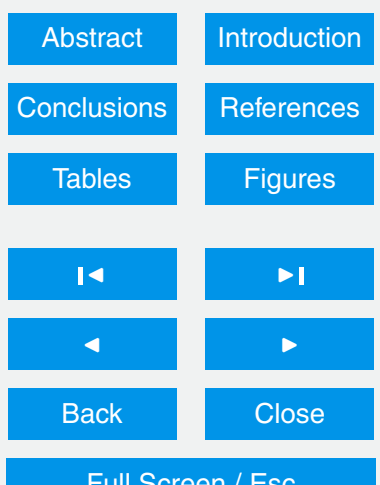

Full Screen / Esc

Printer-friendly Version

Interactive Discussion 
The MLS useful data range for $\mathrm{O}_{3} \mathrm{VMR}, \mathrm{H}_{2} \mathrm{O}$ VMR and $T$ are as follows for the pressure level range $261-0.02,316-0.002$ and $261-0.001 \mathrm{hPa}$ respectively. The data accuracy in the height range considered for observation is $4-9 \%$.

\subsection{MIPAS-ENVISAT data for $\mathrm{CH}_{4}$ VMR}

5 MIPAS (Michelson Interferometer for Passive Atmospheric Sounding) is a limbscanning Fourier infrared spectrometer on board the European Environmental Satellite (ENVISAT); more detailed characteristics regarding the measurements bythis spaceborne instrument are given by Carli et al. (2004) and Raspollini et al. (2006). The sunsynchronous polar orbit provides a global coverage with nearly 14 orbits per day at a horizontal resolution of approximately $500 \mathrm{~km}$. More than 20 trace constituents are observed in the upper troposphere and in the stratosphere. Currently, the MIPAS level-2 operational products are provided by the European Space Agency (ESA). These products include the temperature, and the concentrations of $\mathrm{H}_{2} \mathrm{O}, \mathrm{CH}_{4}, \mathrm{~N}_{2} \mathrm{O}, \mathrm{O}_{3}, \mathrm{HNO}_{3}$ and $\mathrm{NO}_{2}$. In its original nominal measurement mode, MIPAS scanned the Earth limb at 17 tangent altitudes of $6,9, \ldots, 39,42,47,52,60$, and $68 \mathrm{~km}$. The vertical resolution is $3 \mathrm{~km}$ for the 13 lower most tangent altitudes and increases to $8 \mathrm{~km}$ at the upper end of the limb scan. MIPAS $\mathrm{CH}_{4}$ VMR data has been compared with satellite instruments including ACE-FTS, HALOE, SOFIE and SCIAMACHY (Laeng et al., 2015). Above $50 \mathrm{~km}$ altitude, MIPAS methane mixing ratios agree almost perfectly with ACE, and above 40been found. In the lower stratosphere (below about 25-30 km) MIPAS $\mathrm{CH}_{4}$ is biased high, and the most likely esimate of this bias is 0.2 ppmv. MIPAS data are available for the years 2002-2012. In this study, methane volume mixing ratio data have been taken from MIPAS-ENVISAT data source for the SSWs occurred in 2004, 2009 and 2012.

\section{ACPD}

15, 23969-23988, 2015

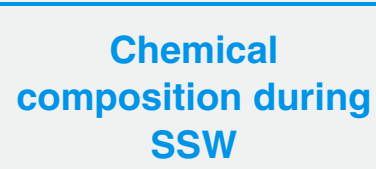

O. Nath and S. Sridharan

Title Page

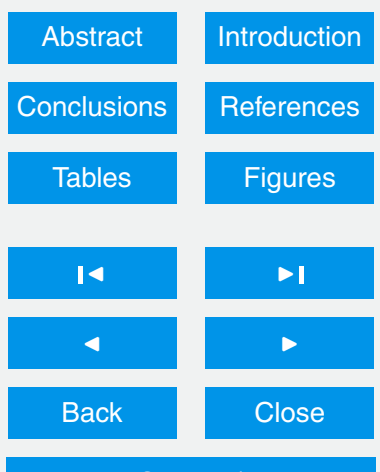

Full Screen / Esc

Printer-friendly Version

Interactive Discussion 


\subsection{ECMWF ERA-Interim data for zonal wind and temperature}

ERA-Interim is the latest European Centre for Medium-Range Weather Forecasts (ECMWF) global atmospheric reanalysis of the period 1979 to present (Berrisford, 2009). This follows on from the ERA-15 and ERA-40 re-analysis projects. The datasets

5 include data on surface, PV, potential temperature and pressure surfaces. The ECMWF has in the past produced three major reanalyses: FGGE, ERA-15 and ERA-40. The last of these consisted of a set of global analyses describing the state of the atmosphere and land and ocean-wave conditions from mid-1957 to mid-2002. The ERA-Interim is an "interim" reanalysis of the period 1989-present in preparation for the next-generation extended reanalysis to replace ERA-40.

In this present study, ERA-Interim data have been used for the observation of zonal wind as well as temperature (grid $1.5^{\circ} \times 1.5^{\circ}$ ) variations for the pressure levels 100 $1 \mathrm{hPa}$ during the SSWs of 2004, 2009 and 2012.

\section{Results}

\section{$3.12011 / 12$ winter and equatorial temperature and ozone}

Figure $1 a$ and $b$ shows the zonal mean of ERA- Interim temperature difference between 90 and $60^{\circ} \mathrm{N}$ and of ERA- Interim zonal wind at $60^{\circ} \mathrm{N}$ respectively for the pressure levels $100-1 \mathrm{hPa}$ and for the duration 1 December 2011 to 18 February 2012. The SSW is normally identified from the positive temperature between 90 and $60^{\circ} \mathrm{N}$ latitudes at $10 \mathrm{hPa}$. Before day number 43 , the temperature difference is -10 to $-20 \mathrm{~K}$, which means that the temperature at $60^{\circ} \mathrm{N}$ is more than that at $90^{\circ} \mathrm{N}$ indicating that the normal cold winter is prevailing. A clear sudden enhancement in temperature can be observed from day number 43 in the height range $10-1 \mathrm{hPa}$. When the warming starts the temperature difference becomes positive, as the polar stratospheric temperature is increased by several kelvins. Here the temperature difference between 90 and $60^{\circ} \mathrm{N}$
ACPD

15, 23969-23988, 2015

Chemical

composition during

ssW

O. Nath and S. Sridharan

Title Page

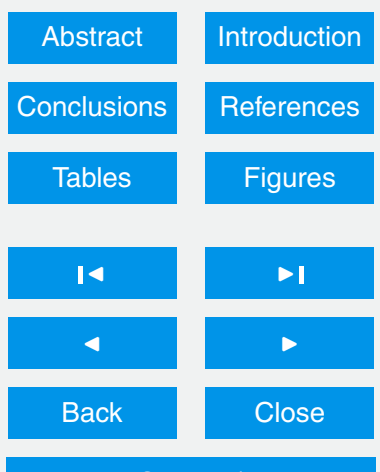

Full Screen / Esc

Printer-friendly Version

Interactive Discussion 
rises upto $16 \mathrm{~K}$ (on day number 55 ) and it remains positive during day numbers 43-64, which indicates the duration of the SSW. When the SSW occurs, the polar westerly wind gets decelerated up to $5 \mathrm{~ms}^{-1}$ and as it does not get reversed to easterly, this event is considered only as a minor SSW. Figure 1c and e show the altitude profiles of 5 MLS zonal mean of ozone $\left(\mathrm{O}_{3}\right)$ VMR and temperature over the equator for the height region 20-60 km for the duration of 1 December 2011 to 18 February 2012. As the onset of SSW takes place, $\mathrm{O}_{3}$ VMR shows enhancement, whereas temperature and water vapor decrease in the middle and upper stratosphere from day number 49 . Though the onset of SSW is marked on day number 43 at $10 \mathrm{hPa}$, it may be noted that the polar

10 temperature starts to increase from day number 29 at higher heights $(>10 \mathrm{hPa})$. Time mean removed zonal mean $\mathrm{O}_{3} \mathrm{VMR}$ and temperature have been plotted in Fig. 1d and Fig. $1 f$ respectively. It can be observed from the figures that there is an increase in the time mean removed ozone VMR by about 0.6 ppmv during day number 29-35, whereas the temperature decreases by a value $\sim 4 \mathrm{~K}$ from day number 29 .

\subsection{8/09 winter and equatorial temperature and ozone}

Figure $2 \mathrm{a}$ and $\mathrm{b}$ shows the zonal mean of ERA-Interim temperature difference between 90 and $60^{\circ} \mathrm{N}$ and of ERA-Interim zonal wind at $60^{\circ} \mathrm{N}$ respectively for the pressure levels $100-1 \mathrm{hPa}$ for the time period 1 December 2008 to 18 February 2009. The temperature difference is around -10 to $-15 \mathrm{~K}$ before the day number 52 and it becomes positive 20 from day number 52 in the height range $10-1 \mathrm{hPa}$ indicating the onset of the SSW event. It reaches a maximum of $25.8 \mathrm{~K}$ on day number 54 and the positive temperature difference (the SSW event) persists during the day numbers 52-57. The zonal mean wind at $60^{\circ} \mathrm{N}$ becomes westward on day number 55 at and above $10 \mathrm{hPa}$ revealing that the SSW event is a major one. Figure 2c and e show the altitude profiles of zonal mean of ozone $\left(\mathrm{O}_{3}\right)$ VMR and temperature over the equator obtained from MLS for the heights $20-60 \mathrm{~km}$ for the duration of 1 December 2008-18 February 2009. For more clear interpretation, Fig. $2 \mathrm{~d}$ and $\mathrm{f}$ are plotted which show time mean removed zonal mean ozone VMR and temperature. Day number 52 onwards, the time mean

\section{ACPD}

15, 23969-23988, 2015

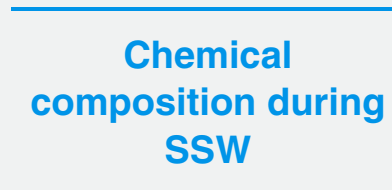

O. Nath and S. Sridharan

Title Page

Abstract

Introduction

Conclusions

References

Tables

Figures

14

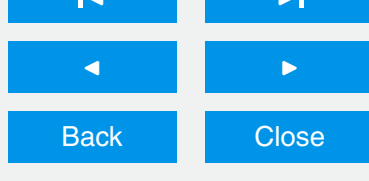

Full Screen / Esc

Printer-friendly Version

Interactive Discussion 
removed $\mathrm{O}_{3}$ VMR increases, reaches a high value of around $0.8 \mathrm{ppmv}$ and gradually reduces after day number 60 . The time mean removed temperature decreases more to a maximum of $-9 \mathrm{~K}$ during day numbers $50-55$. After day number 60 , it starts to become positive again.

\section{3.3 Equatorial water vapor and methane during the 2008/09 SSW}

Figure $3 a$ shows zonal mean temperature difference between 90 and $60^{\circ} \mathrm{N}$ for the pressure levels $10-1 \mathrm{hPa}$ for the time period 1 December 2008 to 18 February 2009 for reference. As shown earlier, the major SSW event occurs during the day numbers 52-57. Figure $3 \mathrm{~b}$ shows time mean removed zonal mean $\mathrm{H}_{2} \mathrm{O}$ VMR over the equator for the height range $20-60 \mathrm{~km}$. Above $40 \mathrm{~km}$, day number 35 onwards the $\mathrm{H}_{2} \mathrm{O} V M R$ starts to decrease by small amount $(\sim 0.1 \mathrm{ppmv})$. As the day of onset approaches, the time removed $\mathrm{H}_{2} \mathrm{O}$ VMR decreases by an amount 0.5 ppmv and it persists up to day number 62. The source of water vapor in this height region (upper stratosphere) is oxidation of methane $\left(\mathrm{CH}_{4}\right)$ (Dessler, 2000; Seinfield and Pandis, 2006). For investigating 15 the $\mathrm{CH}_{4}$ variation during the time of observation, MIPAS onboard ENVISAT data are being considered to show the time mean removed zonal mean $\mathrm{CH}_{4}$ VMR in Fig. 3c. Above $3 \mathrm{hPa}$, time removed $\mathrm{CH}_{4}$ VMR starts to increase from day number 35 , reaches a value around 0.15 ppmv on day number 53. After day number 70 , the $\mathrm{CH}_{4}$ VMR slowly reduces.

\subsection{Equatorial water vapor and methane during the 2011/12 SSW}

In the case of 2011/12 winter, the time mean removed zonal mean $\mathrm{H}_{2} \mathrm{O}$ and $\mathrm{CH}_{4}$ VMR are shown in Fig. 4 along with the state of zonal mean temperature and zonal mean wind as reference. During this winter, a minor SSW event occurs during the day numbers 43-64. However, SSW begins at higher heights from day number 29 (Fig. 4a).

25 Above $40 \mathrm{~km}$, the time mean removed $\mathrm{H}_{2} \mathrm{O}$ VMR starts to decrease from day number 29 and reaches a value $\sim 0.48$ ppmv around day number 45 . After day number 70 ,

\section{ACPD}

15, 23969-23988, 2015

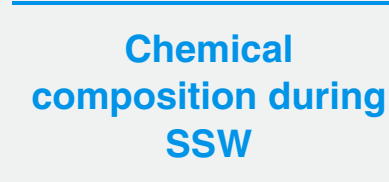

O. Nath and S. Sridharan

Title Page

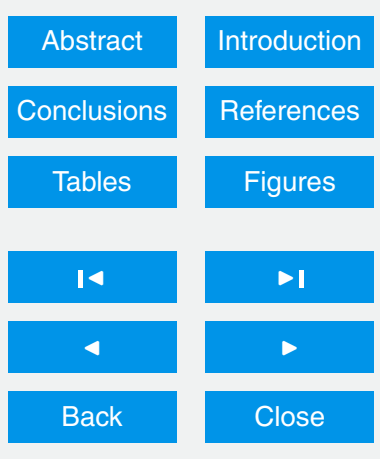

Full Screen / Esc

Printer-friendly Version

Interactive Discussion 
the value reduces. Time mean removed $\mathrm{CH}_{4}$ VMR begins to increase from a value of 0.018 ppmv around day number 30 to a value of 0.15 ppmv around day number 45 . After day number 70 , the value reduces. From these two cases, it is apparent that the minor constituents respond to the temperature variations above $10 \mathrm{hPa}$ rather than 5 at $10 \mathrm{hPa}$, which has been traditionally used to identify the occurrence of SSW. The variations of $\mathrm{H}_{2} \mathrm{O}$ and $\mathrm{CH}_{4}$ are not simply seasonal in nature, as they are quite different in the two winters and their maximum or minimum VMR coincide with the SSW event.

\subsection{Equatorial water vapor and methane during the 2003/04 SSW}

To verify the consistencies of $\mathrm{H}_{2} \mathrm{O}$ and $\mathrm{CH}_{4} \mathrm{VMR}$ variations observed during the two SSW events of 2009 (major) and 2012 (minor), the variations of the minor constituents, during the 2004 major SSW event are also presented. In Fig. 5a zonal mean temperature difference is shown between 90 and $60^{\circ} \mathrm{N}$ for the duration 1 December 200318 February 2004 for the identification of the SSW event. The onset of the warming can be observed on day number 36 and the event persists up to day number 44 . Figure $5 \mathrm{~b}$ and $\mathrm{c}$ show time mean removed zonal mean $\mathrm{H}_{2} \mathrm{O}$ and $\mathrm{CH}_{4}$ VMR over the equator for the same time period. The time mean removed $\mathrm{H}_{2} \mathrm{O}$ VMR shows a decrease from day number 32, reaches a value $\sim 0.7$ ppmv around day number 40 and begins to decrease from day number 60 . The time mean removed $\mathrm{CH}_{4}$ VMR is also observed to increase from day number 30 above $3 \mathrm{hPa}$ and attain a maximum of $\sim 0.17 \mathrm{ppmv}$ on day number 41. Large values of $\mathrm{CH}_{4}$ VMR persist until day number 60 . In this case study the $\mathrm{H}_{2} \mathrm{O}$ and $\mathrm{CH}_{4}$ VMRs show consistent decrease and increase respectively in association with all the SSW events considered here.

\section{Discussion and conclusions}

In the present study, changes in the VMRs of ozone $\left(\mathrm{O}_{3}\right)$, water vapor $\left(\mathrm{H}_{2} \mathrm{O}\right)$ obtained

from the MLS and VMR of methane $\left(\mathrm{CH}_{4}\right)$ obtained from MIPAS over the equator during

\section{ACPD}

15, 23969-23988, 2015

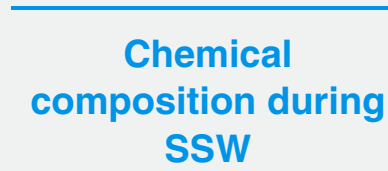

O. Nath and S. Sridharan

Title Page

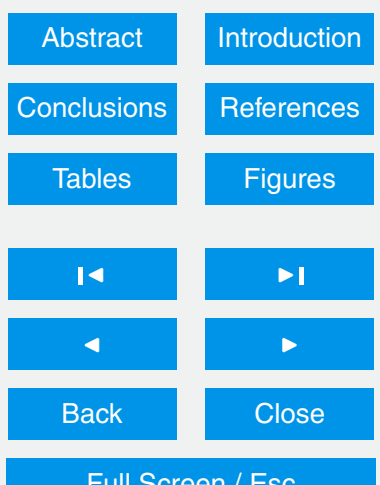

Full Screen / Esc

Printer-friendly Version

Interactive Discussion 
the SSW events of 2004, 2009 and 2012 are studied. The zonal mean temperature difference between 90 and $60^{\circ} \mathrm{N}$ and zonal wind are used to identify the occurrences of the SSW events. The ozone and $\mathrm{CH}_{4}$ VMRs show enhancement as the onset of SSW occurs whereas $\mathrm{H}_{2} \mathrm{O}$ VMR shows a decrease. The observed variation of $\mathrm{H}_{2} \mathrm{O}$ 5 and $\mathrm{CH}_{4}$ VMR during the 2009 and 2012 SSW was verified with the case study of the SSW occured in 2004 which shows similar type of results as observed in case of 2009 and 2012. In the equatorial stratosphere ozone production is due to photolysis of molecular oxygen. This ozone get transported poleward due to BDC (Andrews et al., 1987). During normal time, the $\mathrm{O}_{3}$ concentration is more in higher latitudes compared 10 to that over the equatorial and lower latitudes. During the SSW, the OVMR is found to increase because of the weakening of BDC due to reduction in planetary wave activity with the onset of warming. Sridharan et al. (2012) observed enhancement of ozone during the major SSW of years 2006 and 2009 and suggested as a reason for the enhancement of mesospheric semi-diurnal tide which has been consistenly observed during the major SSW. Nath et al. (2015) also observed increasing OVMR during the 2013 major SSW event. The $\mathrm{H}_{2} \mathrm{O}$ VMR decreases in association with the warming at heights greater than $10 \mathrm{hPa}$. In the upper stratosphere, the main source of water vapor is the oxidation of methane. Oxidation of methane can occur via two ways (Brasseur and Solomon, 1995):

20

$$
\begin{aligned}
& \mathrm{CH}_{4}+\mathrm{O}\left({ }^{1} \mathrm{D}\right) \longrightarrow \mathrm{CH}_{3}+\mathrm{OH} \\
& \mathrm{CH}_{4}+\mathrm{OH} \longrightarrow \mathrm{CH}_{3}+\mathrm{H}_{2} \mathrm{O}
\end{aligned}
$$

Atomic oxygen (O) production results in from the photolysis of $\mathrm{O}_{3}$.

$\mathrm{O}_{3}+h v \rightarrow \mathrm{O}_{2}+\mathrm{O}$

O produced in the above reaction can be in one of two electronic states: ${ }^{3} \mathrm{P}$ ("triplet 25 P") or ${ }^{1} \mathrm{D}$ ("singlet $\mathrm{D}$ "). $\mathrm{O}\left({ }^{1} \mathrm{D}\right)$ is rapidly converted to $\mathrm{O}\left({ }^{3} \mathrm{P}\right)$ through collisions with molecules such as $\mathrm{O}_{2}$ and $\mathrm{CO}_{2}$. So the abundance of more reactive $\mathrm{O}\left({ }^{1} \mathrm{D}\right)$ is much

\section{ACPD}

15, 23969-23988, 2015

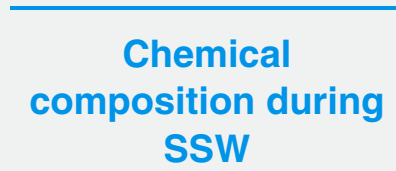

O. Nath and S. Sridharan

Title Page

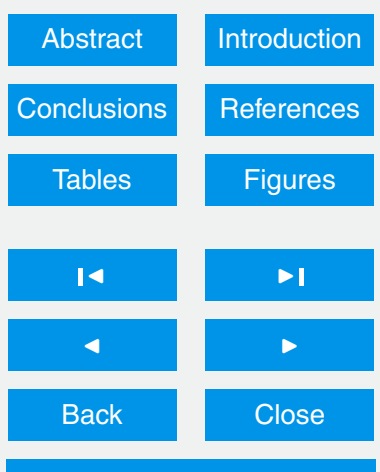

Full Screen / Esc

Printer-friendly Version

Interactive Discussion 
less compared to that of less reactive $\mathrm{O}\left({ }^{3} \mathrm{P}\right)$ in stratosphere (Dessler, 2000). The ozone destruction rate and hence the ozone mixing ratio, are strongly dependent on the mixing ratio of atomic oxygen $\mathrm{O}$. The $\mathrm{O}$ mixing ratio is determined by the $\mathrm{O}$ production (by $\mathrm{O}_{3}$ photolysis, insensitive to temperature) and $\mathrm{O}$ destruction. The oxygen destruction 5 occurs by the reaction

$\mathrm{O}+\mathrm{O}_{2}+\mathrm{M} \longrightarrow \mathrm{O}_{3}+\mathrm{M}$

The rate of the reaction is $k_{0}[\mathrm{O}]^{*}\left[\mathrm{O}_{2}\right]^{*}[\mathrm{M}]$ ([ ] sign stands for concentration) where rate constant $k_{0}=\left(6 \times 10^{-34}\right) \cdot(\mathrm{T} / 300)^{-2.3} \mathrm{~cm}^{6}$ molecules ${ }^{-2} \mathrm{~s}^{-1}$. This three-body reaction is inversely dependent on temperature (Seinfield and Pandis, 2006). A temperature 10 increase as observed during the SSW over higher latitudes results in a decrease of the reaction rate constant of reaction (1) by a factor of approximately 2 which leads to a significantly higher mixing ratio of atomic oxygen (O) and a smaller $\mathrm{O}_{3}$ VMR (Flury et al., 2009). The decrease of temperature over the equatorial latitudes during the SSW events probably shifts the $\mathrm{O} / \mathrm{O}_{3}$ partitioning towards $\mathrm{O}_{3}$, resulting in higher ${ }_{15} \mathrm{O}_{3} \mathrm{VMR}$ and lower atomic oxygen abundance. In the present study variations of hydroxyl (OH) VMR (Fig. 6) over the equator observed by MLS are shown only for the 2009 SSW event, as the MLS data are not available for 2004 and 2012 SSW events. The time mean removed OH VMR shows a very little insignificant decrease of about 0.0001 ppmv during day numbers 48-60 (Fig. 6b). Hence it can be concluded that most probably the reduction of atomic oxygen abundance affects the methane oxidation during the occurrence of SSW events resulting in the decrease in water vapor mixing ratio.

Acknowledgements. The authors acknowledge the Aura-MLS team for providing valuable chemical components datasets and making it available to the scientific community. They are also thankful to ECMRWF for the temperature and winds reanalysis data and MIPAS-ENVISAT

\section{ACPD}

15, 23969-23988, 2015

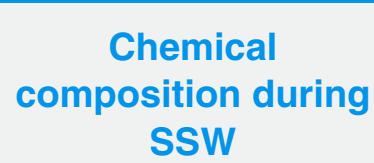

O. Nath and S. Sridharan

Title Page

Abstract

Introduction

Conclusions

References

Tables

Figures

14

4

$>1$

Back

Close

Full Screen / Esc

Printer-friendly Version

Interactive Discussion 


\section{References}

Andrews, D. G., Holton, J. R., and Leovy, C. B.: Middle Atmospheric Dynamics, Acadmic Press, Orlando, 1987.

Brasseur, G. and Solomon, S.: Aeronomy of the Middle Atmosphere: Chemistry and Physics of the Stratosphere and Mesosphere, 3rd Edn., Springer, Dordrecht, the Netherlands, 1995.

Carli, B., Alpaslan, D., Carlotti, M., Castelli, E., Ceccherini, S., Dinelli, B. M., Dudhia, A., Flaud, J. M., Höpfner, M., Jay, V., Magnani, L., Oelhaf, H., Payne, V., Piccolo, C., Prosperi, M., Raspollini, P., Ridolfi, M., Remedios, J., Spang, R.: First results from MIPAS/ENVISAT with operational Level 2 code, Adv. Space Res., 33, 1012-1019, doi:10.1016/S02731177(03)00584-2, 2004.

Damiani, A., Funke, B., López Puertas, M., Gardini, A., von Clarmann, T., Santee, M. L., Froidevaux, L., and Cordero, R. R.: Changes in the composition of the northern polar upper stratosphere in February 2009 after a sudden stratospheric warming, J. Geophys. Res., 119, D51726, doi:10.1002/2014JD021698, 2014.

15 Dutsch, H. U. and Braun, W.: Daily ozone soundings during two winter months including a sudden stratospheric warming, Geophys. Res. Lett., 7, 785-788, doi:10.1029/GL007i010p00785, 1980.

Flury, T., Hocke, K., Haefele, A., Kampfer, N., and Lehmann, R.: Ozone depletion, water vapour increase and PSC generation at midlatitudes by the 2008 major stratospheric warming, J.

$20 \quad$ Geophys. Res., 114, D18302, doi:10.1029/2009JD011940, 2009.

Laeng, A., Plieninger, J., von Clarmann, T., Grabowski, U., Stiller, G., Eckert, E., Glatthor, N., Haenel, F., Kellmann, S., Kiefer, M., Linden, A., Lossow, S., Deaver, L., Engel, A., Hervig, M., Levin, I., McHugh, M., Noël, S., Toon, G., and Walker, K.: Validation of MIPAS IMK/IAA methane profiles, Atmos. Meas. Tech. Discuss., 8, 5565-5590, doi:10.5194/amtd-8-5565$25 \quad 2015,2015$.

Manney, G. L., Daffer, W. H., Strawbridge, K. B., Walker, K. A., Boone, C. D., Bernath, P. F., Kerzenmacher, T., Schwartz, M. J., Strong, K., Sica, R. J., Krüger, K., Pumphrey, H. C., Lambert, A., Santee, M. L., Livesey, N. J., Remsberg, E. E., Mlynczak, M. G., and Russell III, J. R.: The high Arctic in extreme winters: vortex, temperature, and MLS and ACE-FTS trace gas evolution, Atmos. Chem. Phys., 8, 505-522, doi:10.5194/acp-8-505-2008, 2008a.

Manney, G. L., Kruger, K., Pawson, S., Minschwaner, K., Schwartz, M. J., Daffer, W. H., Livesey, N. J., Mlynczak, M. G., Remsberg, E. E., Russell III, J. M., and Waters, J. W.: The evolution of
ACPD

15, 23969-23988, 2015

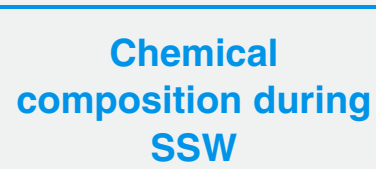

O. Nath and S. Sridharan

Title Page

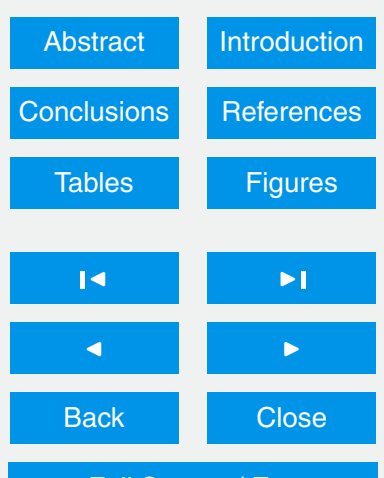

Full Screen / Esc

Printer-friendly Version

Interactive Discussion 
the stratopause during the 2006 major warming: satellite data and assimilated meteorological analyses, J. Geophys. Res., 113, D11115, doi:10.1029/2007JD009097, 2008b.

Manney, G. L., Schwartz, M. J., Krüger, K., Santee, M. L., Pawson, S., Lee, J. N., Daffer, W. H., Fuller, R. A., and Livesey, N. J.: Aura Microwave Limb Sounder observations of dynamics and transport during the record-breaking 2009 Arctic stratospheric major warming, Geophys. Res. Lett., 36, L12815, doi:10.1029/2009GL038586, 2009.

Matsuno, T.: A dynamical model of the stratospheric sudden warming, J. Atmos. Sci., 28, 14791494,doi:10.1175/15200469, 1971.

Nath, O., Sridharan, S., and Gadhavi, H.: Equatorial stratospheric thermal structure and ozone variations during the sudden stratospheric warming of 2013, J. Atmos. Sol.-Terr. Phys., 122, 129-137, doi:10.1016/j.jastp.2014.11.003, 2015.

Randall, C., E., Harvey, V. L., Singleton, C. S., Bernath, P. F., Boone, C. D., and Kozyra, J. U.: Enhanced $\mathrm{NO}_{x}$ in 2006 linked to upper stratospheric Arctic vortex, Geophys. Res. Lett., 33, L18811, doi:10.1029/2006GL027160, 2006.

15 Randall, C. E., Harvey, V. L., Siskind, D. E., France, J., Bernath, P. F., Boone, C. D., and Walker, K. A.: $\mathrm{NO}_{x}$ descent in the Arctic middle atmosphere in early 2009, Geophys. Res. Lett, 36, L18811, doi:10.1029/2009GL039706, 2009.

Raspollini, P., Belotti, C., Burgess, A., Carli, B., Carlotti, M., Ceccherini, S., Dinelli, B. M., Dudhia, A., Flaud, J.-M., Funke, B., Höpfner, M., López-Puertas, M., Payne, V., Piccolo, C., Remedios, J. J., Ridolfi, M., and Spang, R.: MIPAS level 2 operational analysis, Atmos. Chem. Phys., 6, 5605-5630, doi:10.5194/acp-6-5605-2006, 2006.

Salmi, S.-M., Verronen, P. T., Thölix, L., Kyrölä, E., Backman, L., Karpechko, A. Yu., and Seppälä, A.: Mesosphere-to-stratosphere descent of odd nitrogen in February-March 2009 after sudden stratospheric warming, Atmos. Chem. Phys., 11, 4645-4655, doi:10.5194/acp-114645-2011, 2011.

Scherhag, R.: Die explosionsartige Stratosphärenerwarmung des Spätwinters 1951/52, Ber. Deut. Wetterdienstes, 6, 51-63, 1952.

Seinfield, J. H. and Pandis, S. N. Atmospheric Chemistry and Physics: From Air Pollution to Climate Change, 2nd Edn., John Wiley and Sons, Inc., New Jersey, 2006.

30 Siskind, D. E., Eckermann, S. D., Coy, L., McCormack, J. P., and Randall, C. E.: On recent interannual variability of the Arctic winter mesosphere: implications for tracer descent, Geophys. Res. Lett., 34, L09806, doi:10.1029/2007GL029293, 2007.

\section{ACPD}

15, 23969-23988, 2015

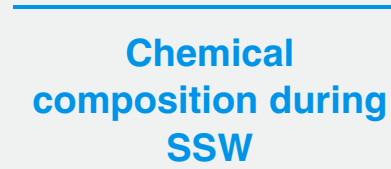

O. Nath and S. Sridharan

Title Page

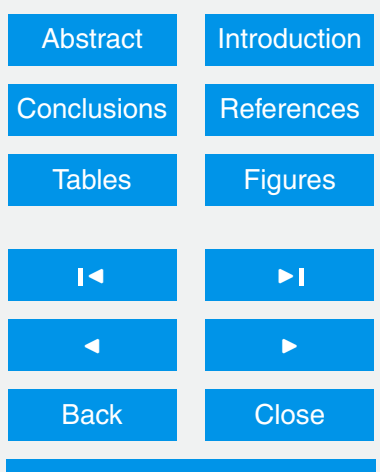

Full Screen / Esc

Printer-friendly Version

Interactive Discussion 
Smith, A. K., López-Puertas, M., García-Comas, M., and Tukiainen, S.: SABER observations of mesospheric ozone during NH late winter 2002-2009, Geophys. Res. Lett., 36, L23804, doi:10.1029/2009GL040942, 2009.

Sofieva, V. F., Kalakoski, N., Verronen, P. T., Päivärinta, S.-M., Kyrölä, E., Backman, L., and 5 Tamminen, J.: Polar-night $\mathrm{O}_{3}, \mathrm{NO}_{2}$ and $\mathrm{NO}_{3}$ distributions during sudden stratospheric warmings in 2003-2008 as seen by GOMOS/Envisat, Atmos. Chem. Phys., 12, 1051-1066, doi:10.5194/acp-12-1051-2012, 2012.

Sridharan, S., Sathishkumar, S., and Gurubaran, S.: Variabilities of mesospheric tides during the sudden stratospheric warming events and their relationship with ozone and water vapour, J. Atmos. Sol.-Terr. Phys., 89, 27-32 doi:10.1016/j.jastp.2012.07.012, 2012.

Tschanz, B. and Kämpfer, N.: Signatures of the 2-day wave and sudden stratospheric warmings in Arctic water vapour observed by ground-based microwave radiometry, Atmos. Chem. Phys., 15, 5099-5108, doi:10.5194/acp-15-5099-2015, 2015.

\section{ACPD}

15, 23969-23988, 2015

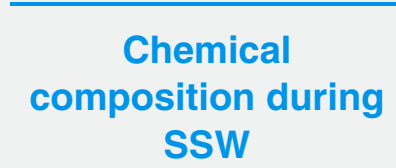

O. Nath and S. Sridharan

\section{Title Page}

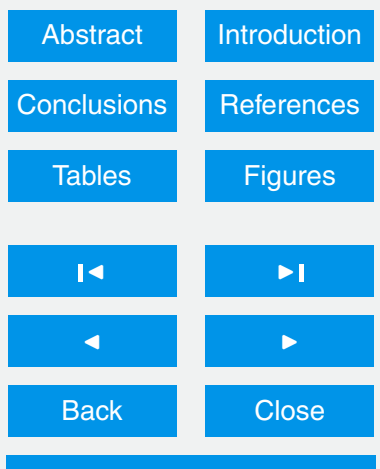

Full Screen / Esc

Printer-friendly Version

Interactive Discussion 

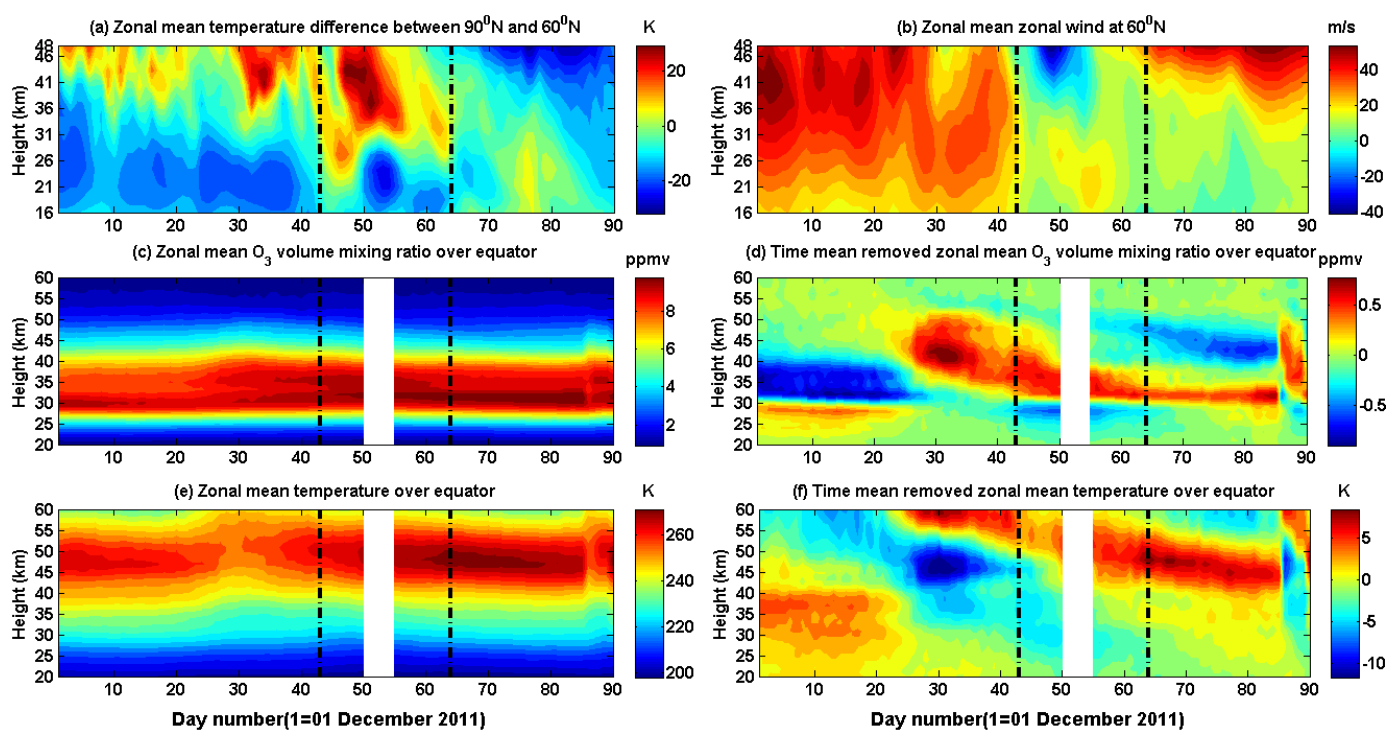

Figure 1. Height profile of (a) ERA-Interim zonal mean temperature difference between 90 and $60^{\circ} \mathrm{N}$, (b) ERA-Interim zonal mean wind at $60^{\circ} \mathrm{N}$, zonal mean Aura-MLS (c) $\mathrm{O}_{3} \mathrm{VMR}$, (e) temperature and time mean removed zonal mean (d) $\mathrm{O}_{3} \mathrm{VMR}$, (f) temperature during 1 December 2011-18 February 2012. The dotted lines represent the duration of the warming event.

\section{ACPD}

15, 23969-23988, 2015

\section{Chemical \\ composition during \\ SSW}

O. Nath and S. Sridharan

Title Page

Abstract

Introduction

Conclusions

References

Tables

Figures

14

4

Back

Close

Full Screen / Esc

Printer-friendly Version

Interactive Discussion 

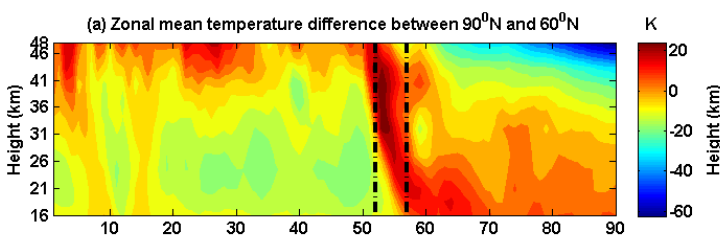

(c) Zonal mean $\mathrm{O}_{3}$ volume mixing ratio over equator

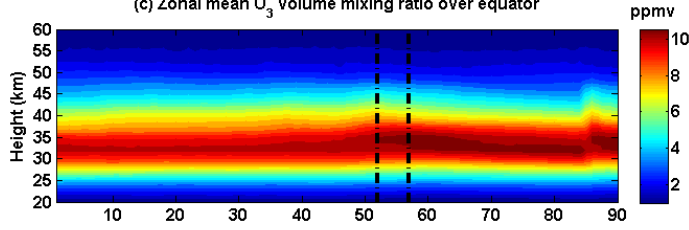

(e) Zonal mean temperature over equator
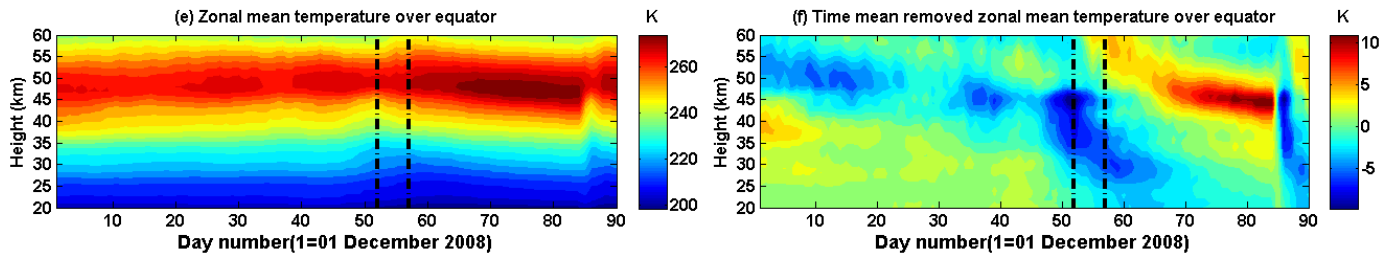

Figure 2. Height profile of (a) ERA-Interim zonal mean temperature difference between 90 and $60^{\circ} \mathrm{N}$, (b) ERA-Interim zonal mean wind at $60^{\circ} \mathrm{N}$, zonal mean Aura-MLS (c) $\mathrm{O}_{3} \mathrm{VMR}$, (e) temperature and time mean removed zonal mean (d) $\mathrm{O}_{3} \mathrm{VMR}$, (f) temperature during 1 December 2008-18 February 2009. The dotted lines represent the duration of the warming event.

\section{ACPD}

15, 23969-23988, 2015

\section{Chemical \\ composition during \\ SSW}

O. Nath and S. Sridharan

Title Page

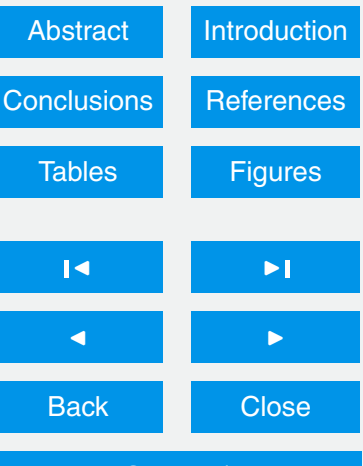

Full Screen / Esc

Printer-friendly Version

Interactive Discussion 


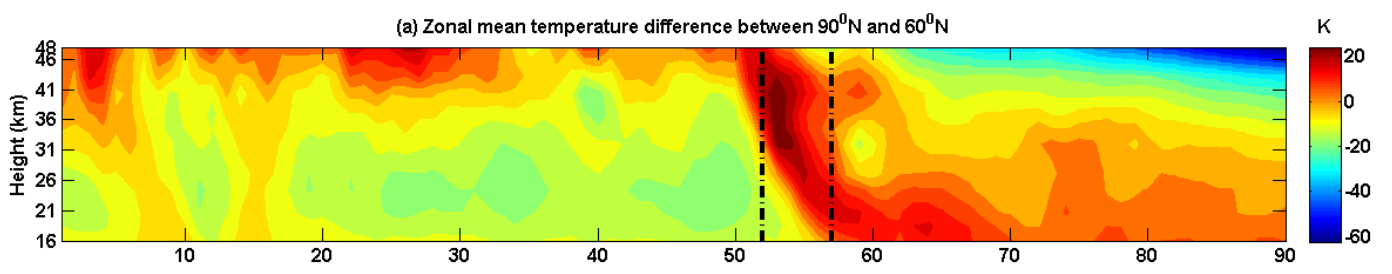

(b) Time mean removed zonal mean $\mathrm{H}_{2} \mathrm{O}$ volume mixing ratio over equator

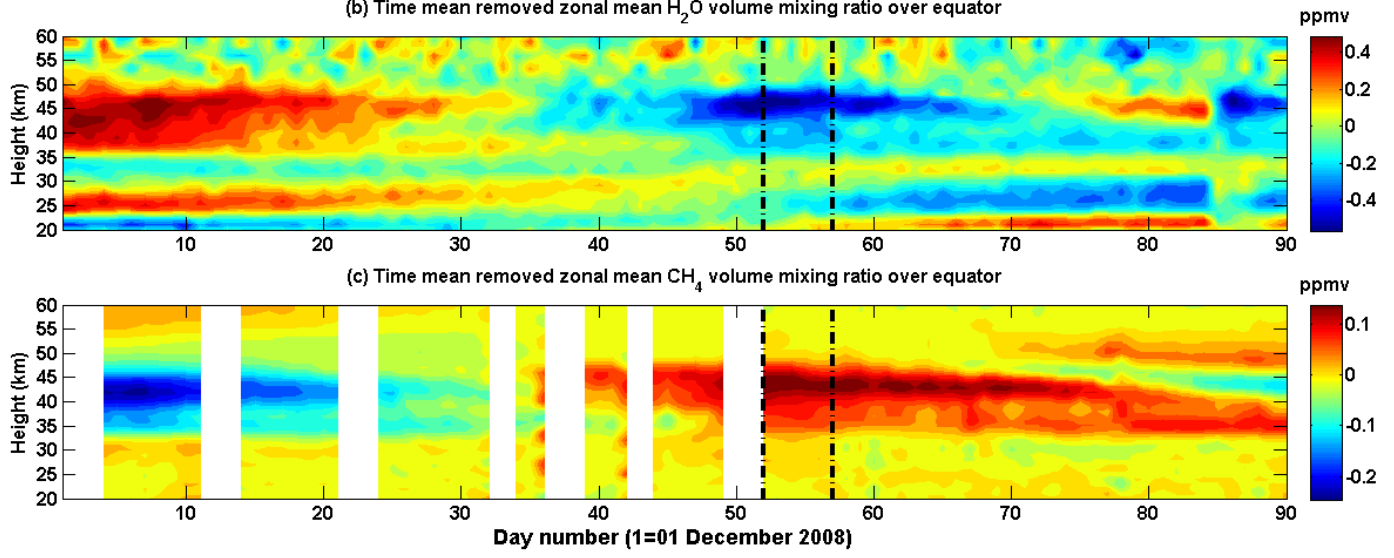

Figure 3. (a) ERA-Interim zonal mean temperature difference between 90 and $60^{\circ} \mathrm{N}$ and time mean removed zonal mean (b) Aura-MLS $\mathrm{H}_{2} \mathrm{O}$ VMR and (c) MIPAS-ENVISAT $\mathrm{CH}_{4}$ VMR over the equator during 1 December 2008-18 February 2009.

\section{ACPD}

15, 23969-23988, 2015

\section{Chemical composition during \\ SSW}

O. Nath and S. Sridharan

\section{Title Page}

\begin{tabular}{|c|c|}
\hline Abstract & Introduction \\
\hline Conclusions & References \\
\hline Tables & Figures \\
\hline I & \\
\hline 4 & $>1$ \\
\hline Back & Close \\
\hline
\end{tabular}

Full Screen / Esc

Printer-friendly Version

Interactive Discussion 

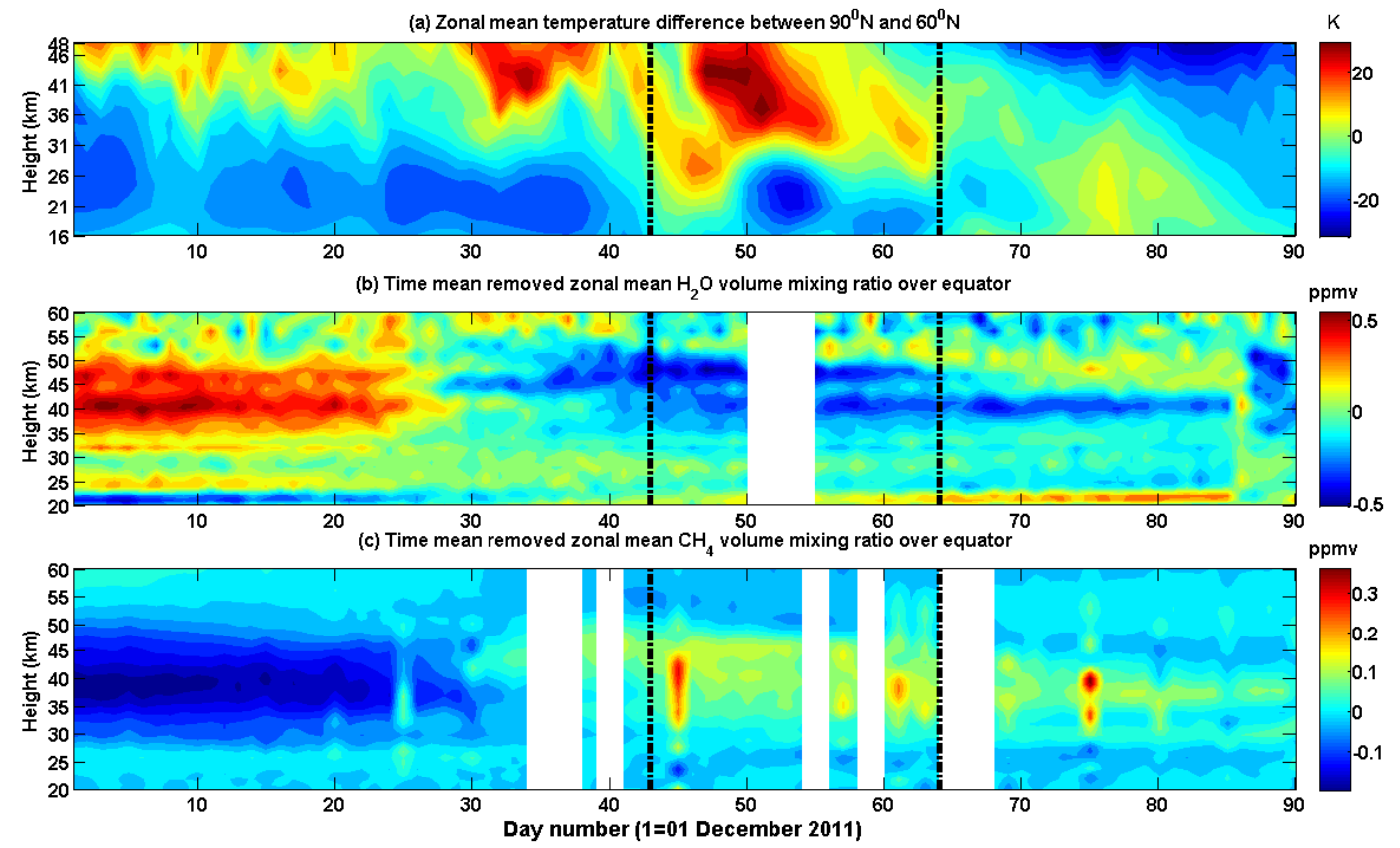

Figure 4. (a) ERA-Interim zonal mean temperature difference between 90 and $60^{\circ} \mathrm{N}$ and time mean removed zonal mean (b) Aura-MLS $\mathrm{H}_{2} \mathrm{O}$ VMR and (c) MIPAS-ENVISAT $\mathrm{CH}_{4}$ VMR over the equator during 1 December 2011-18 February 2012.

\section{ACPD}

15, 23969-23988, 2015

\section{Chemical composition during SSW}

O. Nath and S. Sridharan

\section{Title Page}

\section{Abstract}

Introduction

Conclusions

14

4

Back

lose

Full Screen / Esc

Printer-friendly Version

Interactive Discussion 

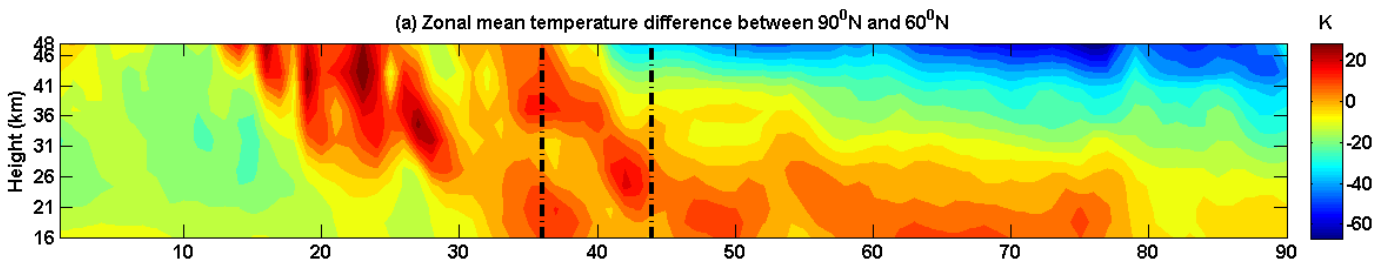

(b) Zonal mean zonal wind at $60^{\circ} \mathrm{N}$
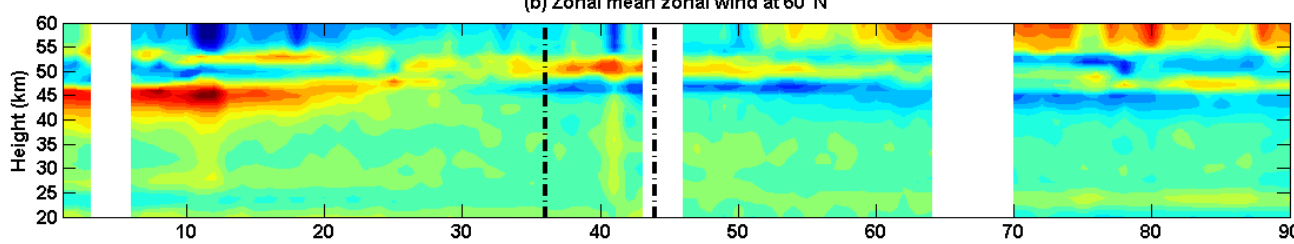

(c) Zonal mean $\mathrm{O}_{3}$ volume mixing ratio over equator

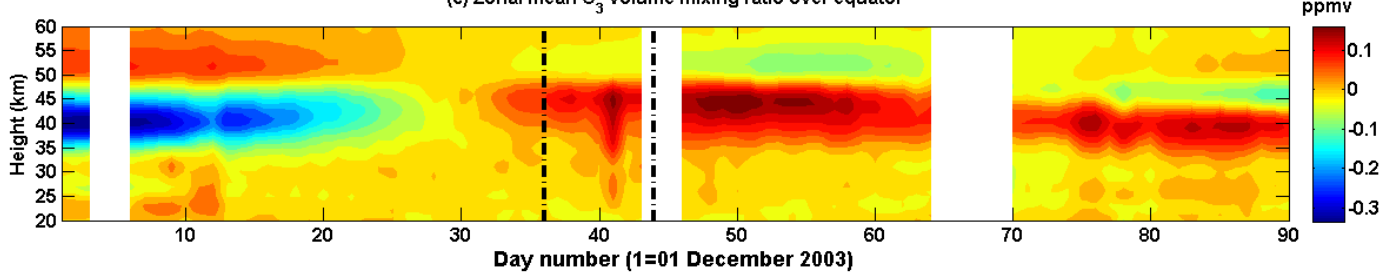

Figure 5. (a) ERA-Interim zonal mean temperature difference between 90 and $60^{\circ} \mathrm{N}$ and time mean removed zonal mean (b) Aura-MLS $\mathrm{H}_{2} \mathrm{O}$ VMR and (c) MIPAS-ENVISAT $\mathrm{CH}_{4}$ VMR over the equator during 1 December 2003-18 February 2004.

\section{ACPD}

15, 23969-23988, 2015

\section{Chemical composition during \\ SSW}

O. Nath and S. Sridharan

\section{Title Page}

\begin{tabular}{|c|c|}
\hline Abstract & Introduction \\
\hline Conclusions & References \\
\hline Tables & Figures \\
\hline I & \\
\hline 4 & $>1$ \\
\hline Back & Close \\
\hline
\end{tabular}

Full Screen / Esc

Printer-friendly Version

Interactive Discussion 

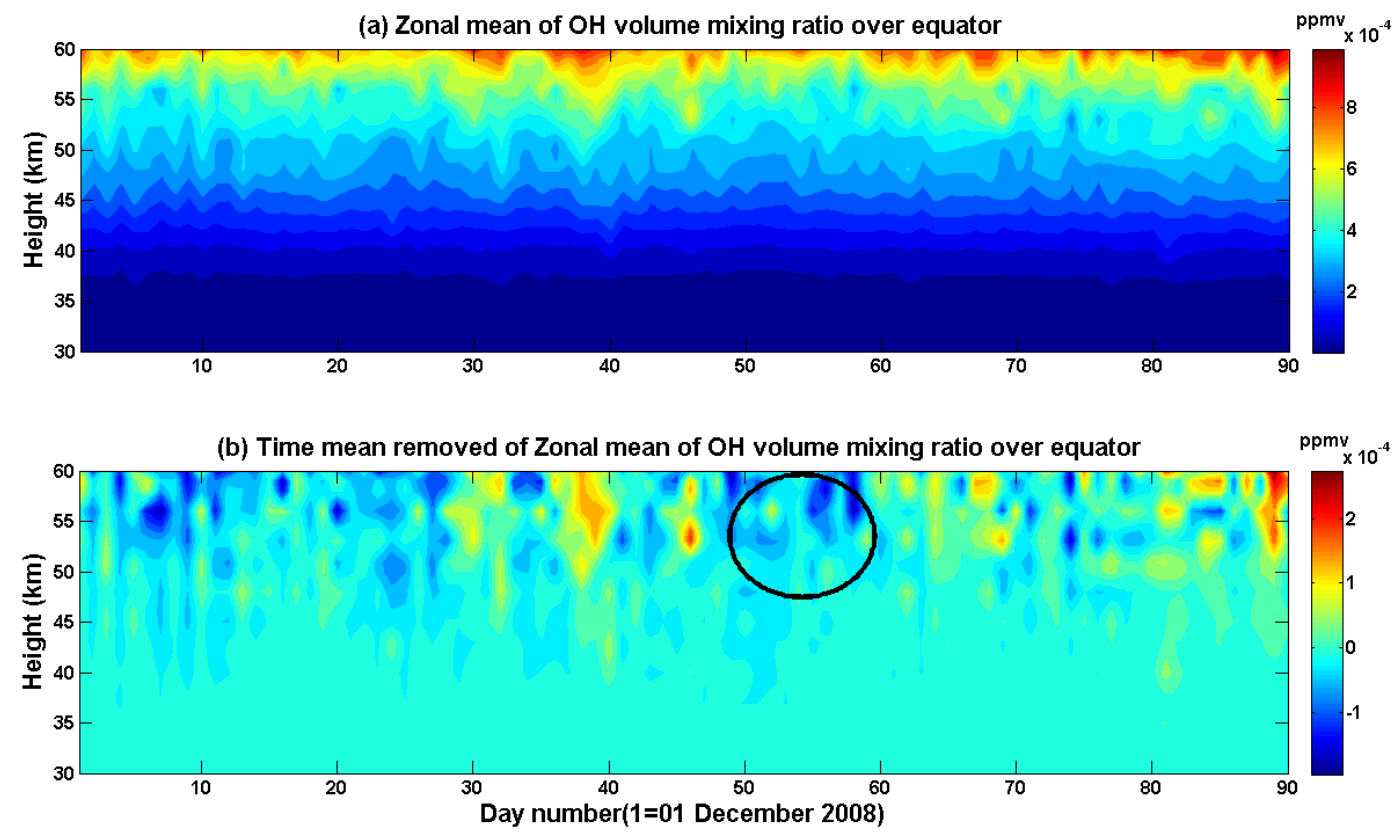

Figure 6. Height-time cross section of Aura-MLS (a) zonal mean and (b) time mean removed zonal mean OH over the equator for 1 December 2008-18 February 2009.

\section{ACPD}

15, 23969-23988, 2015

\section{Chemical composition during SSW}

\section{O. Nath and S. Sridharan}

\section{Title Page}

\section{Abstract}

Introduction

Conclusions

14

4

Back

lose

Full Screen / Esc

Printer-friendly Version

Interactive Discussion 